\title{
ФОРМУВАННЯ ПРОФЕСІЙНОЇ КОМПЕТЕНТНОСТІ - ЗАПОРУКА САМОРЕАЛІЗАЦІЇ МАЙБУТНІХ МЕДИЧНИХ СЕСТЕР ІЗ МАСАЖУ
}

\author{
І. М. Мельничук, А. А. Тєлєгіна \\ ДВНЗ «Тернопільський державний медичний університет \\ імені І. Я. Горбачевського МОЗ Украӥни» \\ КЗОЗ «Харківський обласний медичний коледж»
}

У статті розглянуто основні шляхи формування професійної компетентності під час навчання студентів із вадами зору.

\section{FORMATION OF PROFESSIONAL COMPETENCE - THE KEY TO THE FULFILLMENT OF FUTURE NURSES ON MASSAGE}

\author{
I. M. Melnychuk, A. A. Tieliehina \\ I. Horbachevsky Ternopil State Medical University \\ Kharkiv Regional Medical College
}

The article considers the basic ways of formation of professional competence in teaching students with visual impairments.

Вступ. У сучасному світі, за даними Всесвітньої організації охорони здоров'я, нараховується близько 314 млн людей з вадами зору, 45 млн з яких $\epsilon$ незрячими. На території України проживає близько 200 тис. незрячих та слабозорих.

Узв'язкуз цим, виникає потреба пошукуновихшляхів організації освіти, впровадження інклюзивного навчання у вищому навчальному закладі (ВН3). Результатом такого навчання має стати компетентність випускника ВН3, його здатність успішно виконувати професійні функціональні обов'язки на конкретній посаді.

У працях багатьох зарубіжних та вітчизняних вчених В. Болотова, В. Байденко, Е. Зеєра, І. Зімньої, Т. Іванова, Н. Ничкало, Дж. Равена, А. Хуторського та ін. розглядається питання формування професійної компетентності майбутніх фахівців.

Дослідники В. Андрущенко, І. Бех, С. Бондар, О. Глузман, С. Гончаренко, І. Зязюн, М. Євтух, В. Кремень, Н. Кузьміна, А. Кузьмінський, В. Луговий, Н. Ничкало, А. Хуторський, В. Якунін та ін. приділяють увагу різноманітним аспектам формування професійної компетентності майбутнього фахівця у вищій школі.

(c) І. М. Мельничук, А. А. Тєлєгіна, 2016
У словнику «Професійна освіта» компетентність (від лат. competens - належний, відповідний) визначена як сукупність знань й умінь, необхідних для ефективної професійної діяльності: вміння аналізувати, передбачити наслідки професійної діяльності, використовувати інформацію [3].

Відомо, що 90 \% інформації про оточуючий світ людина отримує завдяки зору. В осіб із вадами зору процес пізнання навколишнього середовища відбувається на основі інших аналізаторів, тому внаслідок неповного або спотвореного сприйняття, уявлення частіше за все фрагментарні, отримана інформація часткова. У своїй книзі «Тифлопсихологія» А. Г. Литвак писав: «Випадання або серйозне обмеження функцій зорового аналізатора дає підставу поставити питання: чи зміняться пізнавальні можливості і адекватність відображення, якщо людина буде мати менше органів чуття, ніж в нормі?» [1].

Основна частина. У Харківському обласному медичному коледжі студенти з вадами зору мають змогу отримати професію медичних сестер із масажу. Підготовку інвалідів із порушенням зору у ВНЗ було розпочато в 1999 р. 
Зазвичай студенти з вадами зору першого року навчання (вчорашні випускники спеціалізованих шкіл-інтернатів) дуже важко адаптовуються до нового навчального середовища, насамперед, це пов'язано зі зміною навчального закладу, розкладу, вивченням нових дисциплін, збільшенням навантаження тощо. Викладачі активно залучають нових студентів до творчої діяльності, науково-пошукової роботи, участі у концертах, де вони мають змогу познайомитись i налагодити спілкування зі здоровими людьми.

Для медичної сестри з масажу під час роботи стане в нагоді вміння спілкуватися з людьми та встановлювати довірливі дружні стосунки.

Важливим завданням навчання людей з обмеженими можливостями $є$ не лише здобуття знань, умінь та навичок, але й соціалізація у суспільстві, формування професійної компетенції, що дозволить випускникам стати затребуваними фахівцями на ринку праці. Навчання студентів із вадами зору, що інтегровані у ВН3, здійснюється відповідно до робочих навчальних програм освітньої установи, які розроблені з урахуванням особливостей сприйняття та основних принципів тифлопедагогіки.

Розглянемо особливості проведення практичних занять з дисципліни «Сестринська справа» у студентів із вадами зору. Практичні заняття проводять у кабінеті доклінічної практики, оснащення якого максимально наближено до умов лікувального закладу та враховано особливості сприйняття навчального матеріалу студентами з вадами зору. Під час занять використовують анатомічні моделі, муляжі, манекени, що дозволяє студентам оволодіти знаннями та практичними навичками. І. М. Сєченов писав: «Рука, обмацуюча зовнішні предмети, дає сліпому все, що дають нам очі, за винятком забарвленості предметів і почуття вдалину, за межі довжини руки». А якщо до цього додати слух, нюх, смак і залишковий зір, то виявиться, що незрячі в принципі володіють пізнавальними можливостями, близькими до можливостей зрячих [2].

При навчанні студентів із вадами зору виправданим $є$ необхідність переходу від традиційних (інформативних) до активних методів та форм навчання.

3 метою формування професійних компетенцій майбутніх фахівців на практичних заняттях із дисципліни «Сестринська справа» використовують найефективніші методи та технології навчання, які сприяють індивідуалізації та інтенсифікації навчального процесу. До них належать: проблемно-пошукові методи; метод проектного навчання; методи колек- тивної розумової діяльності; метод застосування новітніх інформаційно-комунікаційних технологій у навчанні тощо.

Теоретичні матеріали та алгоритми практичних навичок подають у вигляді аудіокниги, що дозволяє підвищити якість навчання і робить навчальний матеріал доступним для цієї категорії студентів. Студенти з вадами зору використовують рельєфно-крапкову систему письма Л. Брайля, яка вже сама по собі зумовлює значне уповільнення процесу засвоєння знань, тому доцільним є застосування диктофона для фіксації матеріалу під час занять.

Використання комп'ютерної програми NVDA (NonVisual Desktop Acces) у процесі проведення занять та при підготовці до них дозволяє студентам із вадами зору отримати необхідну інформацію з монітора без участі зору за допомогою голосу.

Під час роботи за комп'ютером чи ноутбуком для зручного набору тексту студенти з вадами зору використовують адаптивну клавіатуру. Така клавіатура Брайля є зручною при роботі з текстовими файлами: у верхній частині розташовані клавіші для набору, в нижній частині рядок Брайля (призначено для читання текстів, введених за допомогою клавіш). Підключається адаптивна клавіатура за допомогою USB та може використовуватись із звичайною.

Під час проведення практичних занять у бригадах студентів із вадами зору широко використовують кейс-технології, що дозволяє максимально наблизити студентів до професійних завдань у майбутній діяльності на робочому місці, вчить злагодженій праці в команді, розвиває лідерські якості. Для кожної теми практичних занять розроблено кейс, який містить: відео- та аудіофайли, інструменти, матеріали, лікарські засоби з позначкою шрифтом Брайля, предмети індивідуального захисту (фартух, маски, респіратори та ін.), чинні накази МОЗ України, макети для проведення практичних навичок.

Студенти з вадами зору є активними членами професійного гуртка «Серденько». На засіданнях гуртка студенти знайомляться з питаннями інфекційної безпеки, новітніми медичними технологіями, історією медицини та медсестринства в країнах світу та їх розвитком у наш час, можливостями працевлаштування випускників із вадами зору в Україні та за кордоном.

У процесі навчання використовують електронні підручники, збірники вправ, контрольні завдання для поточної та контрольної перевірки знань. У студентів із вадами зору доцільним $\epsilon$ проведення контролю 
теоретичних знань шляхом комп'ютерного тестування. Тестовий метод засновано на визначення рівня підготовки фахівців у певній галузі знань, психологічного, фізичного та розумового стану, професійної придатності, обдарованості та інших якостей особи за допомогою системи спеціально підготовлених знань.

Студенти проводять роботу із запису аудіопортфоліо, метою створення якого є накопичення та збереження документального підтвердження власних досягнень студента в процесі навчання. Складання аудіопортфоліо - творчий процес, що сприяє мотивації до навчальних досягнень та обґрунтованої реалізації самоосвіти для розвитку професійних компетентностей. Розробляють матеріали для профорієнтаційної роботи серед учнів Комунального закладу «Харківський спеціальний навчально-виховний комплекс імені В. Г. Короленка».

\section{ЛІТЕРАТУРА}

1. Литвак А. Г. Тифлопсихология : учеб. пособ. для студентов пед. ин-тов по спец. «Дефектология». - М. : Просвещение, 1985.

2. Особенности познавательной деятельности слепых и слабовидящих школьников / под ред. А. И. Зо-
Висновки. На сучасному етапі в українському суспільстві відбуваються нові соціальні процеси, що торкнулися і ставлення держави до людей з обмеженими фізичними можливостями. Державою передбачено забезпечення їм гідного життя як повноправним членам суспільства відповідно до їх можливостей, індивідуальних здібностей. Важливим питанням у осіб з інвалідністю є вибір професії та здобуття професійної компетенції як запоруки впевненості у майбутньому. Професійна підготовка у ВНЗ людей з обмеженими фізичними можливостями, зокрема з вадами зору, має ряд особливостей: необхідно створити умови для адаптації студентів у ВНЗ, враховувати індивідуальні особливості та розробити індивідуальну траєкторію навчання, використовуючи особистісно-орієнтоване навчання та принципи тифлопедагогіки.

това, А. Г. Литвака. - Л. : Изд-во ЛГПИ им. А. И. Герцена, 1974. - 210 c.

3. Професійна освіта : словник / [уклад. С. У. Гончаренко та ін.] ; за ред. Н. Г. Ничкало. - К. : Вища школа, 2000. - 380 c. 